\title{
Influence of Corn and Millet Starches as Fat Substitutes on Cake Quality
}

\author{
Email address: \\ Dr.Ola-salah-farid@hotmail.com (O. S. Ibrahim) \\ ${ }^{*}$ Corresponding author
}

Ola S. Ibrahim*, Ghada A. Alfauomy, Mona M. A. Ali

Crops Technology Research Department, Food Technology Research Institute, Agricultural Research Center, Al-Giza, Egypt

To cite this article:

Ola S. Ibrahim, Ghada A. Alfauomy, Mona M. A. Ali. Influence of Corn and Millet Starches as Fat Substitutes on Cake Quality. International Journal of Nutrition and Food Sciences. Vol. 5, No. 5, 2016, pp. 352-360. doi: 10.11648/j.ijnfs.20160505.16

Received: August 31, 2016; Accepted: September 12, 2016; Published: October 10, 2016

\begin{abstract}
Current dietary guidelines focus on lowering dietary fat and increasing complex carbohydrate intake. In the present study, two grain starches corn and millet were used to produce resistant starch (RS) and used as partially fat replacer (at $12.5,25,37.5$ and $50 \%$ ) in cakes. The effect of the level of fat substitution on the physicochemical and sensory properties as well as starch digestibility and shelf life of the cakes were investigated. The study showed that moisture content of the products was increased by increasing the level of fat substitution. The caloric values of produced cakes were lower than that of control. The specific volume of cakes were higher at 12.5 and $25 \%$ fat replacement levels. In contrast, cake density decreased by increasing shortening replacement level up to $25 \%$, it was lower and reached $0.38 \mathrm{~g} \mathrm{~cm}^{-3}$ in relative to control $(0.41 \mathrm{~g} \mathrm{~cm})$. TPA values cleared that cake prepared with 12.5 and $25 \%$ substitution levels were less hardness. Increasing the replacement level more than $25 \%$ increased the cake hardness, gumminess and chewiness. Results of color analysis showed a significant increase in $\mathrm{L}$ value and a decrease in $\mathrm{b}$ value. The highest decrement in starch digestibility was observed at $50 \%$ replacement level. The use of (RS) does not change the taste and improve sensory properties of produced cakes. The shelf life based on the microbial examination of the cake for all samples and control recorded 2 weeks.
\end{abstract}

Keywords: Corn, Millet, RS, Fat, Calorie, TPA, Analysis, Shelf Life

\section{Introduction}

In a report of a Joint FAO/WHO Expert Consultation, resistant starch is defined as dietary fiber as well as resistant starch that escapes digestion in the human small intestine appears to have a unique combination of physiological and functional properties compared to traditional types of fiber. Namely, the consumption of high amount of resistant starches may improve glucose and lipid metabolism, can reduce the risk of diabetes mellitus type 2, coronary, and heart diseases as well as colorectal cancer and other gastrointestinal disorders [1].

Resistant starch has been classified into four general subtypes called RS1, RS2, RS3 and RS4 [1]. In a study on humans. The consumption of resistant starch type III (RS3) resulted in lower serum glucose and insulin levels than obtained with other carbohydrates [2]. The study also showed that food containing RS decreased postprandial blood glucose and might play a role in providing improved metabolic control in type II diabetes [3]. Most rich food is characterized and dominated by the high-glycemic effect, which has been associated with an increased risk of chronic disease like obesity, cardiovascular disease and some kind of cancers [4]. A reduction in the glycemic response of carbohydrate food appears to be accompanied by a higher content in resistant starch [5], and RS type III promotes slow to moderate post-prandial glucose and insulin response [6].

RS3 refers to non-granular starch-derived materials that resist digestion. Starch granules are disrupted by heating in an excess of water in a process commonly known as gelatinization, which renders the molecules fully accessible to digestive enzymes.

However, if these starch gels are then cooled 
(retrogradation), they form starch crystals that are resistant to enzymes digestive. It may formed in cooked food that are kept at low or room temperatures, therefore, most moisture heat treated foods contain some RS3 [1]. RS3 is of particular interest, because of its thermal stability $[7,3,1]$.

Additionally, resistant starches have desirable physicochemical properties making it useful in a variety of foods. Moreover, resistant starches do not significantly influence the sensory properties of starch-based products (bread, pasta, cookies, pudding, yoghurt etc.). The demand for the application of resistant starch as a functional ingredient is growing. Thus, the analysis of its structural, thermal, rheological and digestibility properties have a great importance [1].

Fat is one of the important ingredients influencing the sensory characteristics of baked products. Attempts have been done to replace the fat with other food components in baked products to reduce the total calories as well as to enhance nutritional properties. Among the substituting materials, carbohydrates are widely used in baked products, partly because they have economical advantages over many other fat substitutes [8].

The optimum conditions of moisture content, $\mathrm{pH}$, temperature, duration of heating, repeated heating-cooling cycles, etc., make the content of RS may reached as much as $30 \%$. RS is shown to improve eating qualities [9]. The physical properties of resistant starch, particularly its good water-holding capacity, make it a functional ingredient that provides good handling and improves texture in the final product [10].

There is also an increasing interest in using resistant starch (RS) to lower the energy value and available carbohydrate content of foods [11]. Resistant starch provides many technological properties, such as better texture appearance and mouthfeel than conventional fibers [12].

Bakery products constitute one of the most consumed foods in the world. Among them, cakes are popular and are associated in the consumer's mind with a delicious sponge product with desired organoleptic characteristics [13].

The butter cake is a complex fat and water emulsion system containing flour, sugar, fat, eggs and baking powder. A proper combination of these ingredients could give a high quality cake product with desirable flavor and texture [14]. However, due to its high glycemic index, over-consumption may contribute to chronic diseases. The glycemic indices of cake products vary continuously from about 67 to $87 \%$ [15]. In addition the baking industry has responded to the demands of consumers by developing low- or reduced-fat products. Low-fat products normally contain fat substitutes and are produced using formula or processing modifications [16].

The objective of this study is to investigate the impact of partially fat substitution of cake by corn and millet resistant starch (RS) on physicochemical and sensory attributes in the tasted cake samples.

\section{Materials and Methods}

\subsection{Materials}

Wheat flour, white fine sugar, skim milk, shortening, baking powder, vanilla and fresh whole eggs were purchased from the local market. The corn starch was obtained from Egyptian company of Starch and Glucose, Turra factory, Cairo, Egypt. Organic white creamy millet grain produced in USA.

\subsection{Methods}

\subsubsection{Isolation of Millet Starch}

Millet starch was isolated according to the method of Bhupender et al., (2013) [17]. Briefly, Millet grains were steeped in distilled water (w:v, $1: 2$ ) at $4{ }^{\circ} \mathrm{C}$ for $24 \mathrm{~h}$. The excess water was decanted and the steeped and washed grains were ground in a Warning blender with sufficient water. The slurry was sieved on 85 mesh nylon bolting cloth. The left-overs (hulls, germ and endosperm) were reslurried with sufficient water to float off the germ and hulls. The grinding, sieving and regrinding for the left over endosperm particles was repeated until the left-overs were essentially free of starch. The starch-protein slurry was centrifuged at $2000 \mathrm{rpm}$ for $20 \mathrm{~min}$. The supernatant was discarded and the protein layer on top of the starch removed with spatula. The starch was repeatedly washed by re-dispersing inadequate distilled water amounts and centrifuging until it became clean. The cleaned starch was air-dried on a glass plate for 12 $\mathrm{hr}$, re-dispersed in water and wet-sieved through 100- mesh screen. The starch passing through the screen was recovered by centrifugation $(2000 \mathrm{rpm}, 20 \mathrm{~min}$; and dried in hot air oven at $40^{\circ} \mathrm{C}$.

\subsubsection{Resistant Starch Preparation (RS)}

Corn and millet starch are used to produce RS. The method of RS prepared was adapted according to Sievert and Pomeranz (1989) [18]. Starch sample (200 g) was weighed into a 1,000-ml beaker and mixed with $700 \mathrm{ml}$ of distilled water. The starch-water suspension was autoclaved at 20 psi (125 C) for $1 \mathrm{hr}$. After autoclaving, the sample was cooled to room temperature. After three autoclaving-cooling cycles, RS stored overnight in a refrigerator at $4 \pm 1 \mathrm{C}$. (Lin Po-Ying et al., 1994) [19].

\subsubsection{Cake Preparation}

Cakes were prepared according to the formula of Lin PoYing et al., (1994) [19]. The cake formula is listed in Table (1). The control cake was prepared by mixing the sugar and shortening were creamed for 3 min at speed 5 in an kitchen aid mixture. The whole eggs were added and mixed in at the same speed for $2 \mathrm{~min}$. The flour, baking powder and skim milk were add and the batter was mixed for $4 \mathrm{~min}$. at speed 2 . To prepare the replacer cakes the shortening (fat weight basis) in the formula was replaced with corn and millet RS $(0,12.5,25$, 37.5 and $50 \%$ ). Cake batter was placed in cupcake model and was baked in an electric oven for $35 \mathrm{~min}$ at $180^{\circ} \mathrm{C}$. After baking, cakes were removed from the pans and left at room temperature for $1 \mathrm{hr}$. to cool down. Then, were placed on 
polyethylene pouches and sealed to prevent drying.

Table 1. Cake Formula ingredients.

\begin{tabular}{ll}
\hline Ingredient & Amounts \\
\hline Wheat flour & $100 \mathrm{~g}$ \\
Salt & $2.0 \mathrm{~g}$ \\
Shortening & $40-20 \mathrm{~g}$ \\
Sugar & $90 \mathrm{~g}$ \\
Baking powder & $5.0 \mathrm{~g}$ \\
RS (starch gel) & $0-20$ \\
Whole eggs & $44 \mathrm{~g}$ \\
Skim milk & $71 \mathrm{ml}$ \\
Vanilla & $0.5 \mathrm{~g}$ \\
\hline
\end{tabular}

\subsubsection{Analytical Methods}

The proximate chemical composition, ie. moisture, crude protein, total fat and ash of raw materials and cake samples were determined according to AOAC (2005) [20]. Total carbohydrate were calculated by difference. In vitro starch digestibility was assessed by following the method of Singh et al., (2006) [21]. Total calories of cake were calculated by the following equation as reported by James (1995) [22].

$$
\text { Energy value }=4(\text { protein }+g \text { carbohydrates })+9(g \text { fat })
$$

\subsubsection{Physical Measurements of Cake}

Cake weight $(\mathrm{g})$ was recorded after cooling for $1 \mathrm{hr}$. Cake volume $\left(\mathrm{cm}^{3}\right)$ was determined by rapeseed displacement method as described by AACC (2002) [23]. Specific volume $\left(\mathrm{g} \mathrm{cm}^{-3}\right)$ of cake was calculated by dividing volume by weight. Density $\left(\mathrm{g} \mathrm{cm}^{-3}\right)$ was calculated by dividing weight by volume.

\subsubsection{Texture Profile Analysis (TPA) of Cake}

Hardness, cohesiveness, adhesiveness, gumminess and chewiness of cupcakes were measured using Brookfield Engineering Lab. Inc., Middleboro, MA 02346- 1031 USA. The cupcake was sliced in half across its diameter and a 25 $\mathrm{mm}$ wide longitude slice was taken from one of the halves. The measurement was taken at three different side points from the left, center and right perpendicular to the slice, with $40 \%$ compression based on AACC (2002) [24] method 7409.01 .

\subsubsection{Color Evaluation}

The color of cake crumb was measured according to the method outlined by McGurie (1992) [24]. Crumb color was measured on opposite sides of cake by using a hand-held tristimulus reflectance Colorimeter Minolta Chroma Meter (model CR-400, Konica Minolta, Japan). The apparatus provided $\mathrm{L}$ (lightness with $\mathrm{L}=100$ for lightness, and $\mathrm{L}=$ zero for darkness), a [(chromaticity on green $(-)$ to red $(+)], b$ [(chromaticity on a blue $(-)$ to yellow $(+)]$.

\subsubsection{Sensory Evaluation of Cake}

Freshly prepared cake samples were organoleptically evaluated immediately after baked for their sensory characteristics. Slice of each cake sample was served to well trained ten panelists on white, odorless and disposable plates. Samples were scored for shape, crust color, crust vision characteristics, crumb color, brightness, crumb texture, softness, taste, odor and total score (sum of all the tested attributes). The evaluation was carried out according to Bennion and Bamford (1983) [25].

\subsubsection{Microbiology}

The microbiological quality of stored cake for 3 weeks at an ambient temperature was evaluated by determining total fungal count (1 gm sample) using malt yeast agar media to be as a good tool to estimate the shelf life according to Mislivec et al., (1992) [26] and aerobic plate count using total count media (Swanson et al., 1992) [27].

\subsubsection{Statistical Analysis}

For the analytical data, mean values and standard deviation are reported. The obtained data were subjected to one-way analysis of variance (ANOVA) at $\mathrm{P}<0.05$. It was performed and the results were separated using the Multiple Range Duncan's test using the SAS (1987) [28] statistical software.

\section{Results and Discussion}

\subsection{Proximate Analysis of Cake}

The proximate composition of the cake samples replaced with different levels of corn and millet resistant starch (RS) are presented in Table 2. Cake samples containing (12.5, 25, 37.5 , and $50 \%$ ) resistant starch were observed to have higher moisture content than the control. Increment resistant starch levels had been shown to increase the moisture content of cake samples, ranged from 25.24 to 28.86 and $29.91 \%$ in cake samples replaced with corn and millet RS, respectively. The reason is may be attributed to the good water binding capacity of the resistant starch. These results are agreement with (Majzoobi et al., 2014) [29]. Results showed no significant differences in protein content between control and cake samples. 
Table 2. Chemical composition of cake (\%dry weight).

\begin{tabular}{lllllll}
\hline Sample & \multicolumn{1}{l}{ Moisture\% } & *Protein\% & ${ }^{\text {*Fat\% }}$ & *Ash\% & *T. C\% & *Calories \\
\hline 1 & $25.24^{\mathrm{f}}$ & $11.04^{\mathrm{b}}$ & $18.48^{\mathrm{a}}$ & $1.60^{\mathrm{f}}$ & $68.88^{\mathrm{h}}$ & $486.00^{\mathrm{a}}$ \\
2 & $25.89^{\mathrm{e}}$ & $11.72^{\mathrm{a}}$ & $15.54^{\mathrm{c}}$ & $1.83^{\mathrm{b}}$ & $70.91^{\mathrm{g}}$ & $470.36^{\mathrm{c}}$ \\
3 & $28.06^{\mathrm{d}}$ & $11.79^{\mathrm{a}}$ & $12.72^{\mathrm{e}}$ & $1.83^{\mathrm{b}}$ & $73.65^{\mathrm{d}}$ & $456.23^{\mathrm{e}}$ \\
4 & $28.50^{\mathrm{c}}$ & $11.19^{\mathrm{b}}$ & $11.94^{\mathrm{fg}}$ & $1.87^{\mathrm{a}}$ & $75^{\mathrm{c}}$ & $452.22^{\mathrm{g}}$ \\
5 & $28.86^{\mathrm{b}}$ & $11.04^{\mathrm{b}}$ & $10.89^{\mathrm{h}}$ & $1.88^{\mathrm{a}}$ & $76.18^{\mathrm{a}}$ & $446.89^{\mathrm{h}}$ \\
6 & $26.00^{\mathrm{e}}$ & $11.04^{\mathrm{b}}$ & $15.94^{\mathrm{b}}$ & $1.70^{\mathrm{d}}$ & $71.33^{\mathrm{f}}$ & $472.88^{\mathrm{b}}$ \\
7 & $28.54^{\mathrm{c}}$ & $11.10^{\mathrm{b}}$ & $13.93^{\mathrm{d}}$ & $1.70^{\mathrm{d}}$ & $73.27^{\mathrm{e}}$ & $462.79^{\mathrm{d}}$ \\
8 & $28.91^{\mathrm{b}}$ & $10.89^{\mathrm{b}}$ & $12.21^{\mathrm{f}}$ & $1.64^{\mathrm{e}}$ & $75.25^{\mathrm{bc}}$ & $454.45^{\mathrm{f}}$ \\
9 & $29.91^{\mathrm{a}}$ & $11.04^{\mathrm{b}}$ & $11.83^{\mathrm{g}}$ & $1.75^{\mathrm{c}}$ & $75.38^{\mathrm{b}}$ & $452.17^{\mathrm{g}}$ \\
\hline
\end{tabular}

$1=$ un replaced cake, $2=12.5 \%$ fat replacement cake with corn $\mathrm{RS}, 3=25 \%$ fat replacement cake with corn $\mathrm{RS}, 4=37.5 \%$ fat replacement cake with corn RS, $5=50 \%$ fat replacement cake with corn RS, $6=12.5 \%$ fat replacement cake with millet RS, $7=25 \%$ fat replacement cake with millet RS, $8=37.5 \%$ fat replacement cake with millet RS and $9=50 \%$ fat replacement cake with millet RS

*Protein, fat, ash, total carbohydrate (T. C) and total calorie content are calculated on dry basise.

Data are averages from three independent trials

Data in the same column with different letters are significantly different $(\mathrm{p}<0.05)$

Slight changes were observed in ash content compared with control. Fat content decreased linearly with substitution replacement level. The total carbohydrate content increased significantly with increasing the replacement level. The calories reduced from $486 \mathrm{Kcal}$. in control cake to 456.23 in cake replaced with $25 \%$ corn $\mathrm{RS}$, while calories reduced to $462.79 \mathrm{Kcal}$. in cake replaced with millet RS. Thus adding corn or millet RS as fat replacer succeeded to reduce the energy of produced cake which were favorably, compensated the cake product. The use of resistant starch in the diet as a bioactive functional food component is a natural, endogenous way in reducing energy intake, so may be an effective natural approach to the treatment of obesity [30].

\subsection{Physical Properties of Cake}

Physical Properties of Cake replaced with corn and millet resistant starch as fat replacer are shown in Table 3. It showed that cake in which $12.5 \%$ and $25 \%$ of shortening was replaced by corn resistant starch had the highest cake volume 145 and $143 \mathrm{~cm}^{3}$ compared with control cake $135 \mathrm{~cm}^{3}$. Cake volume decreased as the replacement level increased. Specific volume was also increased at $12.5 \%$ and $25 \%$ replacement levels, it reached 2.57 and $2.60 \mathrm{~g} \mathrm{~cm}^{-3}$ compared with control $2.40 \mathrm{~g} \mathrm{~cm}^{-3}$. On contrary the cake density decreased by increasing shortening replacement level up to $25 \%$. The lowest density was observed at the level of $25 \%$ corn RS, it reached $0.38 \mathrm{~g} \mathrm{~cm}^{-3}$ compared with control $0.41 \mathrm{~g} \mathrm{~cm}^{-3}$.

Regarding to millet resistant starch (as shortening replacer) the results revealed that the volume of cake replaced with millet resistant starch increased by increasing the replacement level up to $37.5 \%$ which had the highest value $141.33 \mathrm{~cm}^{3}$ compared with $135.67 \mathrm{~cm}^{3}$ in control cake. Similar trend was observed in specific volume, it reached $2.48 \mathrm{~g} \mathrm{~cm}^{-3}$ at $37.5 \%$ replacement level then it decreased at $50 \%$. The cake density decreased by increasing shortening replacement level up to $25 \%$. The replaced cake at $25 \%$ and $37.5 \%$ had the same density $0.40 \mathrm{~g} \mathrm{~cm}^{-3}$ compared with $0.41 \mathrm{~g} \mathrm{~cm}^{-3}$ in control.

From above mention data, these results suggested that $12.5 \%$ and $25 \%$ of corn resistant starch (as shortening replacement) have similar ability to retain air during cake baking while in case of millet resistant starch (as shortening replacement), $37.5 \%$ had ability to retain more air during baking.

Table 3. Physical properties of cake.

\begin{tabular}{lllll}
\hline Sample & Volume $\left(\mathbf{c m}^{\mathbf{3}}\right)$ & Weight $(\mathbf{g})$ & Specific volume $\left(\mathbf{g} \mathbf{~ c m}^{-3}\right)$ \\
\hline 1 & $135.67^{\mathrm{d}}$ & $56.30^{\mathrm{a}}$ & $2.40^{\mathrm{e}}$ & Density $\left.^{\mathrm{a}} \mathbf{g} \mathbf{~ c m}^{-3}\right)$ \\
2 & $145.67^{\mathrm{a}}$ & $56.80^{\mathrm{a}}$ & $2.56^{\mathrm{b}}$ & $0.41^{\mathrm{b}}$ \\
3 & $142.67^{\mathrm{b}}$ & $54.35^{\mathrm{b}}$ & $2.62^{\mathrm{a}}$ & $0.39^{\mathrm{e}}$ \\
4 & $130.00^{\mathrm{e}}$ & $53.94^{\mathrm{b}}$ & $2.40^{\mathrm{e}}$ & $0.38^{\mathrm{f}}$ \\
5 & $128.67^{\mathrm{e}}$ & $54.55^{\mathrm{b}}$ & $2.35^{\mathrm{f}}$ & $0.41^{\mathrm{b}}$ \\
6 & $136.33^{\mathrm{d}}$ & $56.44^{\mathrm{a}}$ & $2.41^{\mathrm{e}}$ & $0.42^{\mathrm{a}}$ \\
7 & $139.67^{\mathrm{c}}$ & $57.12^{\mathrm{a}}$ & $2.44^{\mathrm{d}}$ & $0.41^{\mathrm{b}}$ \\
8 & $141.33^{\mathrm{bc}}$ & $57.09^{\mathrm{a}}$ & $2.48^{\mathrm{c}}$ & $0.40^{\mathrm{c}}$ \\
9 & $136.33^{\mathrm{d}}$ & $56.84^{\mathrm{a}}$ & $2.39^{\mathrm{e}}$ & $0.40^{\mathrm{c}}$ \\
\hline
\end{tabular}

$1=$ un replaced cake, $2=12.5 \%$ fat replacement cake with corn RS, $3=25 \%$ fat replacement cake with corn RS, $4=37.5 \%$ fat replacement cake with corn RS, $5=$ $50 \%$ fat replacement cake with corn RS, $6=12.5 \%$ fat replacement cake with millet $\mathrm{RS}, 7=25 \%$ fat replacement cake with millet $\mathrm{RS}$, $8=37.5 \%$ fat replacement cake with millet RS and $9=50 \%$ fat replacement cake with millet RS.

Data are averages from three independent trials

Data in the same column with different letters are significantly different $(p<0.05)$

\subsection{Texture Profile Analysis (TPA) of Cake}

Resistant starch have a good water binding capacity, viscosity, swelling power and gel formation, which make it fine application in a variety of foods [1, 31-32]. It is known that one of the roles of fat in cake is the incorporation and stabilization of air cells [33-34]. So the decrease in cake volume was expected as the more replacement of the shortening was done. The textural parameters analysis from
TPA test are presented in Table 4. Cake prepared with $12.5 \%$ and $25 \%$ corn resistant starch replacer level were more softer (less hardness) than that of control cake. In addition cakes prepared with the replacer at 37.5 and $50 \%$ replacement levels were harder than control cake.

These results were in agreement with those obtained by Paraskevoulou and Kiosseoghou (1997) and khalil (1998) [35-36] who reported that cakes prepared with fat replacers at 
$25 \%$ level were softer than control.

Table 4. Texture profile analysis (TPA) of cake.

\begin{tabular}{llllll}
\hline Sample & Hardness $(\mathbf{k g})$ & Cohesiveness & Gumminess $(\mathbf{k g})$ & Chewiness $(\mathbf{k g})$ & Springiness \\
\hline 1 & $0.88^{\mathrm{e}}$ & $0.61^{\mathrm{ef}}$ & $0.53^{\mathrm{e}}$ & $0.45^{\mathrm{e}}$ & $0.83^{\mathrm{c}}$ \\
2 & $0.74^{\mathrm{g}}$ & $0.61^{\mathrm{f}}$ & $0.45^{\mathrm{g}}$ & $0.36^{\mathrm{g}}$ & $0.79^{\mathrm{d}}$ \\
3 & $0.69^{\mathrm{i}}$ & $0.61^{\mathrm{de}}$ & $0.42^{\mathrm{h}}$ & $0.33^{\mathrm{h}}$ & $0.79^{\mathrm{d}}$ \\
4 & $0.96^{\mathrm{c}}$ & $0.63^{\mathrm{b}}$ & $0.61^{\mathrm{c}}$ & $0.48^{\mathrm{c}}$ & $0.80^{\mathrm{d}}$ \\
5 & $0.99^{\mathrm{b}}$ & $0.63^{\mathrm{b}}$ & $0.63^{\mathrm{b}}$ & $0.57^{\mathrm{b}}$ & $0.91^{\mathrm{a}}$ \\
6 & $0.78^{\mathrm{f}}$ & $0.61^{\mathrm{d}}$ & $0.48^{\mathrm{f}}$ & $0.36^{\mathrm{f}}$ & $0.75^{\mathrm{e}}$ \\
7 & $0.72^{\mathrm{h}}$ & $0.63^{\mathrm{c}}$ & $0.45^{\mathrm{g}}$ & $0.33^{\mathrm{h}}$ & $0.74^{\mathrm{e}}$ \\
8 & $0.88^{\mathrm{d}}$ & $0.63^{\mathrm{ab}}$ & $0.56^{\mathrm{d}}$ & $0.48^{\mathrm{d}}$ & $0.85^{\mathrm{b}}$ \\
9 & $1.1^{\mathrm{a}}$ & $0.64^{\mathrm{a}}$ & $0.70^{\mathrm{a}}$ & $0.58^{\mathrm{a}}$ & $0.83^{\mathrm{c}}$ \\
\hline
\end{tabular}

$1=$ un replaced cake, $2=12.5 \%$ fat replacement cake with corn RS, $3=25 \%$ fat replacement cake with corn RS, $4=37.5 \%$ fat replacement cake with corn RS, $5=$ $50 \%$ fat replacement cake with corn RS, $6=12.5 \%$ fat replacement cake with millet RS, $7=25 \%$ fat replacement cake with millet RS, $8=37.5 \%$ fat replacement cake with millet RS and $9=50 \%$ fat replacement cake with millet RS.

Data are averages from three independent trials

Data in the same column with different small letters are significantly different $(\mathrm{p}<0.05)$

Cohesiveness quantifies the internal resistance of food structure. It is the ability of a material to stick to itself. The TPA results showed no significant differences between control and replaced cake when corn starch resistant (as fat replacer) was used.

Gumminess is determined by hardness multiplied by Cohesiveness. The TPA results showed a decrease in gumminess at 12.5 and $25 \%$ replacement levels. While it increased by increasing the level of replacement, the TAP results showed a decrease in cake springiness as the level of fat replacer increased.

Regarding to millet resistant starch (as a fat replacer). The TPA results showed a decrease in hardness at 12.5 and $25 \%$ replacement levels, while cake of $37.5 \%$ replacement level had a similar hardness to control. In addition, TPA results showed an increase in hardens of cake at 50\% replacement level.

The results showed an increase in cohesiveness of cakes with increasing the replacement level. Gumminess Chewiness was decreased at 12.5 and $25 \%$ replacement level, then they increased with increasing replacement level.

In general, increasing the replacement level more than 25\% caused an increase in hardness, gumminess and chewiness where as the springiness was decreased. No significant differences in cohesiveness of cake replaced with corn resistant starch but it insignificantly increased with increasing the replacement level of millet resistant starch.

\subsection{Starch Digestibility of Produced Cake}

In vitro starch digestibility of cakes prepared with corn and millet RS (as shortening replacement) are shown in Table 5. As compared with control, cake in which $12.5 \%$ of shortening was replaced by corn or millet resistant starch showed insignificant differences on starch digestibility. While increase the replacement level to $25 \%$ lowered the starch digestibility from 83.5 to $78.5 \%$. The highest reduction in starch digestibility was observed at $50 \%$ corn and millet RS replacement level.
Table 5. Starch digestibility of produced cake.

\begin{tabular}{ll}
\hline Sample & Starch digestibility \% \\
\hline 1 & $83.50^{\mathrm{a}}$ \\
2 & $83.00^{\mathrm{a}}$ \\
3 & $78.50^{\mathrm{b}}$ \\
4 & $76.25^{\mathrm{bcd}}$ \\
5 & $74.75^{\mathrm{de}}$ \\
6 & $82.50^{\mathrm{a}}$ \\
7 & $78.25^{\mathrm{bc}}$ \\
8 & $76.00^{\mathrm{cd}}$ \\
9 & $73.00^{\mathrm{e}}$ \\
\hline
\end{tabular}

$1=$ un replaced cake, $2=12.5 \%$ fat replacement cake with corn RS, $3=25 \%$ fat replacement cake with corn RS, $4=37.5 \%$ fat replacement cake with corn RS, $5=50 \%$ fat replacement cake with corn RS, $6=12.5 \%$ fat replacement cake with millet RS, $7=25 \%$ fat replacement cake with millet RS, $8=37.5 \%$ fat replacement cake with millet RS and $9=50 \%$ fat replacement cake with millet RS.

Data are averages from three independent trials

Data in the same column with different letters are significantly different $(\mathrm{p}<0.05)$

Resistant starch could be produced from retrogradation of gelatinized starch and known as a resistant starch type III (RS3) which has been cause a reduction in glycemic response due to possibility to increase the resistance towered digestive enzymes [37-38]. The glycemic indices of cake products vary continuously from about 67 to $87 \%$ [15].

Slowly digestible starch content was increased by autoclaving cooling cycle method. Slowly digestible starch, an important starch derivative could be obtained by modification of starch [39].

\subsection{Color of Cake Crumb}

Table 6 presents the results of the color of produced cakes. The color of starch affects the color of the finished product. A bright white color starch is more desirable for product development. The $\mathrm{L}$ value was a parameter for characterizing starch color, its lightness and it was a direct measurement of its whiteness. The $\mathrm{L}$ value close to 100 indicates whiteness. The chromaticity coordinate a, which ranges from -60 (green) to +60 (red), the chromaticity coordinate $\mathrm{b}$, which 
ranges from -60 (blue) to +60 (yellow) indicated a higher in density of yellow [39]. Color changes gives information about the extent of browning reaction such as carmalization. Millard reaction, degree of cooking and pigment degradation that take place during the starch extraction process [40].Replacement of fat with RS resulted in a significant increase in $\mathrm{L}$ values while revealed a decrease in $\mathrm{b}$ values, indicating lighter and less yellowish crumb. RS is a white color and hence acts in diluting the pigments components of the cake formulation. Therefore, the lightness of the cake samples increased with increase in the RS level.

Table 6. Color of cake crumb.

\begin{tabular}{lllll}
\hline Sample & L & A & B & Color \\
\hline 1 & $69.2^{\mathrm{h}}$ & $-4.29^{\mathrm{d}}$ & $24.51 \mathrm{f}^{\mathrm{g}}$ & $24.63^{\mathrm{f}}$ \\
2 & $74.95^{\mathrm{c}}$ & $-3.59^{\mathrm{e}}$ & $27.19^{\mathrm{d}}$ & L. Y \\
3 & $75.02^{\mathrm{c}}$ & $-3.42^{\mathrm{f}}$ & $28.62^{\mathrm{b}}$ & V. L. Y \\
4 & $76.06^{\mathrm{b}}$ & $-3.25^{\mathrm{g}}$ & $29.59^{\mathrm{a}}$ & V. L. Y \\
5 & $77.31^{\mathrm{a}}$ & $-3.17^{\mathrm{h}}$ & $27.93^{\mathrm{c}}$ & V. L. Y \\
6 & $71.52^{\mathrm{g}}$ & $-4.68^{\mathrm{c}}$ & $26.74^{\mathrm{e}}$ & V. L. Y \\
7 & $72.69^{\mathrm{f}}$ & $-4.90^{\mathrm{b}}$ & $24.58^{\text {f }}$ & V. L. Y \\
8 & $73.10^{\mathrm{e}}$ & $-4.93^{\mathrm{b}}$ & $24.21^{\text {g }}$ & V. L. Y \\
9 & $74.32^{\mathrm{d}}$ & $-5.02^{\mathrm{a}}$ & V. L. G. Y & V. L. G. Y \\
\hline
\end{tabular}

$1=$ un replaced cake, $2=12.5 \%$ fat replacement cake with corn RS, $3=25 \%$ fat replacement cake with corn RS, $4=37.5 \%$ fat replacement cake with corn RS, $5=$ $50 \%$ fat replacement cake with corn RS, $6=12.5 \%$ fat replacement cake with millet RS, $7=25 \%$ fat replacement cake with millet RS, $8=37.5 \%$ fat replacement cake with millet RS and $9=50 \%$ fat replacement cake with millet RS.

$\mathrm{L}=$ Degree of whiteness (white $+100 \leftrightarrow 0$ black); a: Degree of redness (red $+100 \leftrightarrow-80$ green); b: Degree of yellowness (yellow $+70 \leftrightarrow-80$ blue)

L. Y=Light yellow, V. L. Y=Very light yellow, V. L. G. Y=Very light greenish yellow

Data are averages from three independent trials

Data in the same column with different letters are significantly different $(\mathrm{p}<0.05)$

Crumb color is affected by constituents in the cake formulation [41]. RS (as shortening replacers) had a white color and hence acts in dilution the pigmented components such as fat and eggs in cake formula. Thus the lightness of cakes increased with increment the shortening replacement level. Similar results also reported by Baixauli et al., (2008) [42] related to the resistant starch containing muffins.

\subsection{Sensory Evaluation of the Tested Cake}

Sensory evaluation score of the tested cakes attributes are illustrated in Table 7. The results showed that there are no significant differences among replaced samples in shape and crust color. There are also insignificant differences between samples and control in crust characteristics, On the other hand, there are no significant differences in crumb color and brightness between samples and control in case of utilization of the corn RS as a replacer. On contrary crust characteristics decrement of the replaced cake was non significantly as increasing the level of millet fat replacer. Crumb texture also showed a non significantly decrease with increasing the level of both type fat replacements. Taste was slightly decreased in replaced cake samples at 37.5 and 50\% level compared with control, but there were no significant differences between replaced cake at 12.5 and $25 \%$ by the two replacers in relative to control cake. It observed that cakes prepared with 12.5 and $25 \%$ fat replacers had higher mean scores for over all acceptability of both the tested replacers.

It is difficult to get the sensory properties of fat in low moisture bakery food like cookies, espicially in a final moisture between 3-4\%. Normally, increased levels of water are needed to replace high levels of fat, and means of stabilizing the extra water is necessary [16].

Table 7. Sensory evaluation of the tested cake.

\begin{tabular}{|c|c|c|c|c|c|c|c|c|c|c|}
\hline $\mathbf{S}$ & Shape & Crust color & Crust character & Crumb color & brightness & Crumb texture & Softness & Taste & Odor & OAA* \\
\hline 1 & $9.40^{\mathrm{a}}$ & $9.60^{\mathrm{a}}$ & $9.60^{\mathrm{a}}$ & $9.60^{\mathrm{a}}$ & $9.60^{\mathrm{a}}$ & $9.20^{\mathrm{a}}$ & $9.60^{\mathrm{ab}}$ & $14.80^{\mathrm{a}}$ & $14.60^{\mathrm{a}}$ & $96.00^{\mathrm{a}}$ \\
\hline 2 & $9.30^{\mathrm{a}}$ & $9.50^{\mathrm{ab}}$ & $9.60^{\mathrm{a}}$ & $9.40^{\mathrm{a}}$ & $9.30^{\mathrm{ab}}$ & $9.40^{\mathrm{a}}$ & $9.50^{\mathrm{ab}}$ & $14.60^{\mathrm{ab}}$ & $14.40^{\mathrm{a}}$ & $95.00^{\mathrm{a}}$ \\
\hline 3 & $8.90^{\mathrm{a}}$ & $9.50^{\mathrm{ab}}$ & $9.40^{\mathrm{a}}$ & $9.40^{\mathrm{a}}$ & $9.10^{\mathrm{ab}}$ & $9.50^{\mathrm{a}}$ & $9.60^{\mathrm{ab}}$ & $14.20^{\mathrm{ab}}$ & $14.00^{\mathrm{ab}}$ & $93.60^{\mathrm{ab}}$ \\
\hline 5 & $8.60^{\mathrm{a}}$ & $8.60^{\mathrm{ab}}$ & $8.90^{\mathrm{a}}$ & $8.60^{\mathrm{a}}$ & $8.30^{\mathrm{b}}$ & $9.00^{\mathrm{a}}$ & $9.00^{\mathrm{bc}}$ & $13.40^{\mathrm{b}}$ & $13.00^{\mathrm{b}}$ & $87.40^{\mathrm{b}}$ \\
\hline 6 & $9.30^{\mathrm{a}}$ & $9.70^{\mathrm{a}}$ & $9.20^{\mathrm{a}}$ & $9.80^{\mathrm{a}}$ & $9.80^{\mathrm{a}}$ & $9.20^{\mathrm{a}}$ & $9.30^{\mathrm{abc}}$ & $14.40^{\mathrm{ab}}$ & $14.40^{\mathrm{a}}$ & $95.50^{\mathrm{a}}$ \\
\hline 7 & $9.30^{\mathrm{a}}$ & $9.40^{\mathrm{ab}}$ & $8.80^{\mathrm{a}}$ & $9.50^{\mathrm{a}}$ & $9.50^{\mathrm{a}}$ & $9.60^{\mathrm{a}}$ & $9.60^{\mathrm{ab}}$ & $14.10^{\mathrm{ab}}$ & $14.00^{\mathrm{ab}}$ & $93.60^{\mathrm{ab}}$ \\
\hline 9 & $9.00^{\mathrm{a}}$ & $8.80^{\mathrm{ab}}$ & $8.60^{\mathrm{a}}$ & $9.00^{\mathrm{a}}$ & $9.10^{\mathrm{ab}}$ & $8.80^{\mathrm{a}}$ & $8.80^{\mathrm{c}}$ & $13.60^{\mathrm{ab}}$ & $13.80^{\mathrm{ab}}$ & $89.50^{\mathrm{ab}}$ \\
\hline
\end{tabular}

*OAA $=$ Over all acceptability

$1=$ un replaced cake, $2=12.5 \%$ fat replacement cake with corn RS, $3=25 \%$ fat replacement cake with corn RS, $4=37.5 \%$ fat replacement cake with corn RS, $5=$ $50 \%$ fat replacement cake with corn $\mathrm{RS}, 6=12.5 \%$ fat replacement cake with millet $\mathrm{RS}, 7=25 \%$ fat replacement cake with millet $\mathrm{RS}, 8=37.5 \%$ fat replacement cake with millet RS and $9=50 \%$ fat replacement cake with millet RS.

Data are averages from three independent trials

Data in the same column with different letters are significantly different $(p<0.05)$ 
Cakes prepared by using 25 or $50 \%$ fat replacers had higher mean scores for flavor, softness and eating quality than control [36]. The use of resistant starches as food ingredients typically does not change the taste or significantly change the texture, but may improve sensory properties compared with many of the traditionally used fibers, such as bran and gums [3].

\subsection{The Microbial Quality of Cake}

Post-baking contamination can result in the spoilage of certain baked goods if they are un-properly stored for prolonged time. Molds is one of the most common forms of spoilage for baked goods. Foods are spoiled when they contained more than $10^{7}$ or $10^{5} \mathrm{CFU} . \mathrm{ml}^{-1}$ or $\mathrm{g}^{-1}$ of bacteria or molds, respectively [43].

Table 8 displays the total bacterial count of various concentrations of starch on in cake during storage at room temperature for 3 weeks to be a suitable monitor for the shelf life of the product. It showed an increase in log bacterial count by increasing storage time of all samples. Similar trend was found in control. No significant differences ( $5 \%$ level) in total bacterial count among control and12. 5, 25, 37. 5 and $50 \%$ corn RS samples during storage period. The same trend was showed in millet RS replaced samples, where these samples had total bacterial count less than $107 \mathrm{CFUg}^{-1}$. These results are in agreement with those reported by Bazaraaa et al., (2005) [44] who found that, the control samples of cake recorded 5.3 $\mathrm{CFUg}^{-1}$ after 3 weeks which was less than in the rejacted values $\left(107 \mathrm{CFUg}^{-1}\right)$.

Table 8. Total bacterial count in fat replaced cake during storage at room temperature.

\begin{tabular}{|c|c|c|c|c|}
\hline Sample & 0 time & 1 week & 2 week & 3 week \\
\hline 1 & $1.89^{\text {ad }}$ & $2.97^{\mathrm{ac}}$ & $4.90^{\mathrm{ab}}$ & $5.87^{\text {ba }}$ \\
\hline 2 & $1.87^{\mathrm{ad}}$ & $2.87^{\mathrm{ac}}$ & $4.90^{\mathrm{ab}}$ & $6.23^{\mathrm{aba}}$ \\
\hline 3 & $1.86^{\mathrm{ad}}$ & $3.00^{\mathrm{ac}}$ & $5.10^{\mathrm{ab}}$ & $6.23^{\text {aba }}$ \\
\hline 4 & $1.87^{\mathrm{ad}}$ & $2.97^{\mathrm{ac}}$ & $5.00^{\mathrm{ab}}$ & $6.13^{\text {aba }}$ \\
\hline 5 & $1.89^{\mathrm{ad}}$ & $3.01^{\mathrm{ac}}$ & $5.03^{\mathrm{ab}}$ & $6.22^{a b a}$ \\
\hline 6 & $1.88^{\mathrm{ad}}$ & $2.89^{\mathrm{ac}}$ & $4.93^{a b}$ & $6.25^{\mathrm{aba}}$ \\
\hline 7 & $1.85^{\mathrm{ad}}$ & $3.00^{\mathrm{ac}}$ & $5.03^{\mathrm{ab}}$ & $6.26^{\mathrm{aba}}$ \\
\hline 8 & $1.82^{\mathrm{ad}}$ & $2.97^{\mathrm{ac}}$ & $4.97^{\mathrm{ab}}$ & $6.25^{\mathrm{aa}}$ \\
\hline 9 & $1.83^{\mathrm{ad}}$ & $2.80^{\mathrm{ac}}$ & $4.93^{\mathrm{ab}}$ & $6.32^{\mathrm{aa}}$ \\
\hline
\end{tabular}

$1=$ un replaced cake, $2=12.5 \%$ fat replacement cake with corn $\mathrm{RS}, 3=25 \%$ fat replacement cake with corn $\mathrm{RS}, 4=37.5 \%$ fat replacement cake with corn $\mathrm{RS}, 5=50 \%$ fat replacement cake with corn RS, $6=12.5 \%$ fat replacement cake with millet RS, $7=25 \%$ fat replacement cake with millet $\mathrm{RS}, 8=37.5 \%$ fat replacement cake with millet RS and $9=50 \%$ fat replacement cake with millet RS.

Data are averages from three independent trials

Data in the same column with different small letters are significantly different $(\mathrm{p}<0.05)$

Table 9 showed the log fungal count in fat replaced cake during storage for 3 weeks at room temperature. Data showed the count was increased by increasing storage period (3 weeks) in all samples.
Table 9. Log fungal count in fat replaced cake during storage at room temperature.

\begin{tabular}{lllll}
\hline Sample & 0 time & 1 week & 2 week & 3 week \\
\hline 1 & $0.48^{\text {ad }}$ & $1.95^{\text {ac }}$ & $4.40^{\text {ab }}$ & $7.32^{\text {aa }}$ \\
2 & $0.48^{\text {ad }}$ & $2.00^{\text {ac }}$ & $4.47^{\text {ab }}$ & $7.67^{\text {aa }}$ \\
3 & $0.47^{\text {ad }}$ & $1.90^{\text {ac }}$ & $4.67^{\mathrm{ab}}$ & $7.31^{\text {aa }}$ \\
4 & $0.47^{\text {ad }}$ & $2.00^{\text {ac }}$ & $4.43^{\text {ab }}$ & $7.23^{\text {aa }}$ \\
5 & $0.47^{\text {ad }}$ & $2.00^{\text {ac }}$ & $4.57^{\text {ab }}$ & $7.37^{\text {aa }}$ \\
6 & $0.47^{\text {ad }}$ & $1.95^{\text {ac }}$ & $4.69^{\mathrm{ab}}$ & $7.44^{\text {aa }}$ \\
7 & $0.47^{\text {ad }}$ & $2.00^{\text {ac }}$ & $4.71^{\text {ab }}$ & $7.62^{\text {aa }}$ \\
8 & $0.47^{\text {ad }}$ & $1.97^{\text {ac }}$ & $4.58^{\text {ab }}$ & $7.28^{\text {aa }}$ \\
9 & $0.47^{\text {ad }}$ & $1.97^{\text {ac }}$ & $4.64^{\text {ab }}$ & $7.32^{\text {aa }}$ \\
\hline
\end{tabular}

$1=$ un replaced cake, $2=12.5 \%$ fat replacement cake with corn RS, $3=25 \%$ fat replacement cake with corn RS, $4=37.5 \%$ fat replacement cake with corn RS, $5=50 \%$ fat replacement cake with corn RS, $6=12.5 \%$ fat replacement cake with millet RS, $7=25 \%$ fat replacement cake with millet RS, $8=37.5 \%$ fat replacement cake with millet RS and $9=50 \%$ fat replacement cake with millet RS.

Data are averages from three independent trials

Data in the same column with different small letters are significantly different $(\mathrm{p}<0.05)$

From the obtained results, it could be observed that, the control sample was spoiled when stored for 3 weeks, where total fungal count recorded $7.32 \mathrm{CFUg}^{-1}$. Same result were recorded for other samples. So, the shelf life of the cake for all samples and control recorded 2 weeks where these samples had total fungal count less than $10^{5} \mathrm{CFUg}^{-1}$.

\section{Conclusions}

Fat in cake formula can be partially replaced with corn and millet resistant starch (RS) up to $25 \%$ to produce high quality low caloric cake. The caloric values of produced cakes were reduced by increasing levels of replacement. White creamy millet succeeded to produce modified starch with light color that suitable to produce high quality cake similar to corn starch. It is recommended to increase the cultivation in light color millet cultivars in Egypt to be introduced in food industry development. Low starch digestibility and low calorie content of produced cakes have a positive effect for people with obesity, type II diabetes and cardiovascular problems. Thus it is recommended that the resistant starch (RS) could collaborate with bakery products to improve public health.

\section{References}

[1] Tabibloghmany, F. S. and Ehsandoost, E. (2014). Investigation of Nutritional and Functional Properties of Resistant Starch in Food Industry: A Review. International Journal of Recent Research and Review, Vol. VII, Issue 1, March 2014.

[2] Reader, D., Johnson, M. L., Hollander, P., and Franz, M. (1997). Response of resistant starch in a food bar vs. two commercially available bars in persons with type II diabetes mellitus. Diabetes, 46 (1), 254. 
[3] Sajilata, M. G., Singhal, R. S.and Kulkarni, P. R. (2006). Resistant starch - A review. Comprehensive Reviews in Food Science and Food Safety, 5, 1-17.

[4] Barclay A. W., Petocz P., McMillan-Price J., Victoria M. F., Tania P., Paul M. and Brand-Miller J. C. (2008). Glycemic index, glycemic load, and chronic disease risk- a meta analysis of observational. Am J Clin Nut 87: 627-637.

[5] Bjorck I., Liljeberg H. and Ostman E. (2000). Low glycaemicindex foods. Brit J of Nutr 83 (1): S149-S155.

[6] Jenkin C., Kendall W., Augustin L. S., Franceschi S., Hamidi M., Marchie A., Jenkins A. L. and Axelsen M.(2002). Glycemic index: overview of implications in health and disease. Am. J. of Clin Nutr. 76: 266S-273 S

[7] Haralampu, S. G. (2000). Resistant starch: A review of the physical properties and biological impact of RS3. Carbohydrate Polymers, 41, 285-292

[8] Kim H. Y. L., Yeom H. W. Lim H. S, and Lim S.-T. (2001). Replacement of Shortening in Yellow Layer Cakes by Corn Dextrins. Cereal Chem. 78 (3): 267-271.

[9] Tharanathan, R. N. (2002). Food-derived carbohydrates: Structural complexity and functional diversity. Critical Reviews in Biotechnology, 22 (1), 65-84

[10] Baixauli, R., Salvador, A., Martinez-Cervera, S. and Fiszman, S. M. (2008). Distinctive sensory features introduced by resistant starch in baked products. Food Science and Technology, 41, 1927-1933

[11] Nugent, A. P. (2005). Health properties of resistant starch. British Nutrition Foundation, Nutrition Bulletin, 30, 27-54.

[12] Charalampopoulos, D., Wang, R., Pandiella, S. S., and Webb, C. (2002). Application of cereals and cereal components in functional foods: A review. International Journal of Food Microbiology, 79, 131-141.

[13] Matsakidou, A, Blekas, G. and Paraskevopoulou, A. (2010) Aroma and Physical Characteristics of Cakes Prepared by Replacing Margarine with Extra Virgin Olive Oil. LWT-Food Science and Technology, 43, 949957.http://dx.doi.org/10.1016/j.lwt.2010.02.002.

[14] Sahi S. S. and Alava J. M. (2003). Functionality of emulsifiers in sponge cake production. J. of the Sci. of Food and Agri. 83: $1419-1429$.

[15] Foster-Powell, Susanna H. A. Holt, and Janette C. BrandMiller. International table of glycemic index and glycemic load values: (2002). Am J Clin Nutr; 76: 5-56.

[16] Sanchez, C., Klopfenstein, C. F. and Walker C. E.(1995) Use of Carbohydrate-Based Fat Substitutes and Emulsifying Agents in Reduced-Fat Shortbread Cookies. American Association of Cereal Chemists, Inc. Vol. 72. No. 1.

[17] Bhupender, S. K., Rajneesh, B. and Baljeet, S. Y. (2013) Physicochemical, functional, thermal and pasting properties of starches isolated from pearl millet cultivars. International Food Research Journal 20(4): 1555-1561.

[18] Sievert, D., and Pomeranz. Y. (1989). Enzyme-resistant starch. Characterization and evaluation by enzymatic, thermoanalytical, and microscopic methods. Cereal Chem. 66:342.
[19] Lin Po-Ying, Czuchajowska Z and Pomeranz Y., (1994) Enzyme-Resistant Starch in Yellow Layer Cake. Cereal Chem. 71 (1): 69-75.

[20] AOAC (2005) Official Methods of Analysis of AOAC International. 18th Edition, AOAC, Washington D. C.

[21] Singh U; Khardekar M. S. and Jambunathan R. (2006). Studies on desi and Kabuli chickpea (Cicer orietinum) cultivars. The level of amylase inhibitors, level of oligosaccharides and in vitro starch digestability. Journal of Food Science, 47 (2): 510 - 512

[22] James, C. S. (1995) General Food Studies. In: Analytical Chemistry of Foods, Chapter 6, Blachie Academic and Professional, 137-171. http://dx. doi.org/10.1007/978-1-46152165-5 6.

[23] AACC (2002) Approved Method of American Association of Cereal Chemists. Approved Methodsof AACC Published by the American Association of Cereal Chemists. 13th. Ed, St. Paul, Inc. Minnesota.

[24] McGurie, R. G. (1992) Reporting of Objective Color Measurements. HortScience, 27, 1254-1255.

[25] Bennion, E. B. and Bamford, G. S. (1983) The Technology of Cake Making. Leonard Hill Books, Great Britain by Builling and Son's Ed., London, 241 p.

[26] Mislivec, P. B; Beuchat, L. R. and Cousin, M. A. (1992). Yeast and molds. pp. 239-249. In: Compendium of Methods for the Microbiological Examination of Foods, $3^{\text {rd }}$ ed. Vanderzant. C. and Splittstoesser, D. F. (eds.). American Public Health Association, Washington, D. C.

[27] Swanson, K. M. J., Busta, F. F., Peterson, E. H. and Johnson, M. G (1992). Colony count methods. PP. 75-95. In: Compendium of Methods for the Microbiological Examination of Foods, $3^{\text {rd }}$ ed. Vanderzant. C. and Splittstoesser, D. F (eds). American Public Health Association, Washington, D. C.

[28] SAS (1987). Statistical analysis system. Release 6.03. SAS Institute Inc. Carry, Nc. USA.

[29] Majzoobi M., Hedayati S., Habibi M., Ghiasi F., and Farahnaky A., (2014). Effects of Corn Resistant Starch on the Physicochemical Properties of Cake J. Agr. Sci. Tech. Vol. 16: 569-576.

[30] Keenan M. J; Zhou J; Mccutcheon K. L; Raggio A. M; Bateman H. G; and Todd E., (2006). Effects of resistant starch, a nondigestible fermentable fiber, on reducing body fat. Obesity, 14, 1523-1534.

[31] Rahman, S., Bird, A., Regin, A., Li, Z., Ral, J. P, McMaugh, S Toppinga, D and Morella, M. (2007). Resistant starch in cereals: Exploiting genetic engineering and genetic variation. Journal of Cereal Science 46, 251-260. 32. DeVries, J. W. (2004). Dietary fiber: The influence of definition on analysis and regulation. Journal of AOAC International, 87 (3), 682706.

[32] DeVries, J. W. (2004). Dietary fiber: The influence of definition on analysis and regulation. Journal of AOAC International, 87 (3), 682-706.

[33] Bath, D. E., Shelke, K., and Hoseney, R. C.(1992). Fat replacers in highratio layer cakes. Cereal Foods World 37: 495-500. 
[34] Brooker, B. E. (1993). The stabilization of air in cake battersThe role of fat. Food Struct. 12, 285-296.

[35] Paraskevopoulou, A. and V. Kiosseoglou, (1997). Texture profile analysis of heat-formed gels and cakes prepared with low cholesterol egg yolk concentrates. J. Food Sci., 62: 208211.

[36] Khalil, A. H (1998). The influence of carbohydrate-based fat replacers with and without emulsifiers on the quality characteristics of low fat cake. Plant Foods Hum. Nutr 52: 299-313.

[37] Frei M., Siddhuraju P., and Becker K., (2003). Studies on the in vitro starch digestibility and the glycemic index of six different indigenous rice cultivars from the Philippines. Food Chem 83: 395-402.

[38] Pongjanta J, Utaipatanacheep A, Naivikul O. and Piyachomkwan K (2007). Improvement of resistant starch type III formation from high amylose rice starch by enzymatically debranching process. In: Proceedings of the 4th International Conference on Starch Technology, pp 245- 251. Queen Sirikit National Convention Center Bangkok, Thailand.

[39] Thilagavathi T; Banumathi P; Kanachana S; and Ilamaran M. (2015). Effect of heat moisture treatment on functional and phytochemical properties of native and modified millet flours. Plant Archives Vol. 15 NO. 1, 2015 pp 15-21.

[40] Altan A., Kathryn L. McCarthy and Medeni Maskan, (2008). Twin-screw extrusion of barley-grape pomace blends: Extrudate characteristics and determination of optimum processing conditions. Journal of Food Engineering 89, 24 32.

[41] Majzoobi, M., Darabzadeh, N. and Farahnaky, A (2012). Effects of percentage and particle size of wheat germ on some properties of batter and cake. J. Agric. Sci. Technol. 14, 827836.

[42] Baixauli, R., Salvador, A. and Fiszman, S. M (2008). Textural and Color Changes during Storage and Sensory Shelf Life of Muffins Containing Resistant Starch. Eur. J. Food Res. Technol., 226: 523-530.

[43] Mossel, D. A. A; Corry, E. L.; Struijk, C. B. and Baird, R. M. (1995). Essential of the microbiology of foods, a textbook for Advanced studies. John wiley and sons, chichester.

[44] Bazaraa W. A. Riyad Y. M., Abdel Salam S. M. and AlFaumy, G. A. (2005) The antimicrobial activity of maillard reaction products in model and applied systems. Bull. Fac. Agric. Cairo Univ. 56: (4) 813-838. 